\title{
From students to leaders: evaluating the impact on academic performance, satisfaction and student empowerment of a pilot PAL programme among first year students and second year leaders
}

\section{Stacey Scriver}

National University of Ireland Galway, Republic of Ireland

\section{Amber Walsh Olesen}

National University of Ireland Galway Students' Union, Republic of Ireland

\section{Eoghan Clifford}

National University of Ireland Galway, Republic of Ireland

\section{Abstract}

This paper evaluates the pilot year of the CÉIM PAL initiative at the National University of Ireland Galway through analysis of examination results, student surveys and the reflections of two students who participated as first year students in the pilot year and subsequently as student leaders in year two. The paper considers the impact of attendance at sessions on academic performance, student satisfaction with the programme, and evaluates the extent to which the initiative has assisted students to become more empowered learners as expressed through the development of self-directed learning, growth in educational self-efficacy, and confidence in navigating the learning environment. Recommendations are also made for developing the CÉIM initiative, which may be relevant to other PAL programmes and for determining the direction of future research.

Keywords: PAL programme; academic performance; student empowerment; satisfaction. 


\section{Introduction}

At the beginning of my first year I was struggling with homesickness, a lack of friends and trying to acclimatise myself to college life...I wasn't sure if I was supposed to learn it all; how was I supposed to complete assignments - what standard did my lecturers expect from me? I didn't feel brave enough to voice my concerns. (Eniola, student participant and student leader)

On starting the degree I was quite shocked at the workload and the high standard of work expected. [I hadn't been prepared] for the volume of work required on a full time course. (Steven, student participant and student leader)

The experiences outlined by Steven and Eniola above are common for first year students entering university. Students often express uncertainty about how to handle workloads, approach study, and manage their fears and inhibitions in tackling assignments, projects and exams (van der Meer and Scott, 2008; Haggis, 2006). How these issues are handled impacts on student results, retention rates and on individual educational development. Students or learners who are 'empowered' have been found to not only achieve 'greater content learning, but are also thought to better demonstrate competencies such as communication, teamwork, and problem-solving' (Zraa et al., 2013, p.148). Learner empowerment is thus an important element in initiatives such as Peer Assisted Learning (PAL) schemes that aim to improve academic performance, student retention and overall student satisfaction.

At the College of Engineering and Informatics at the National University of Ireland Galway (NUI Galway), a PAL initiative was introduced in the 2013/14 academic year in collaboration with the Students' Union. The programme aimed to assist first year engineering students to adapt to third level education. This paper presents findings from a study of the pilot year of the CÉIM initiative relating to first year attendance at CÉIM sessions and academic performance, student satisfaction with the programme, and learner empowerment. 


\section{Background to CÉIM}

In mid-2012, NUI Galway Students' Union, in collaboration with the College of Engineering and Informatics at NUI Galway, decided to take a more active role in supporting successful student transitions to university. Student and lecturer feedback and assessment of results led to the identification of the following key areas where students required additional support: (i) adapting to university life, (ii) planning and managing workloads, (iii) asking questions, (iv) working together, and (v) self-learning. After conducting desk-based research, it was decided to focus on student led-support within the academic sphere (Thomas, 2012) and PAL was selected as the preferred model to pilot.

CÉIM (which means 'step' or 'degree' in the Gaelic/lrish language) was piloted in the 2013/14 academic year and was made available to all first year engineering students on an opt-out basis, facilitated by 23 leaders drawn from second year engineering students. Groups of first year students met weekly for one hour with two or three trained student leaders throughout the 2013/14 academic year (a total of ten weeks in Semester 1 and ten weeks in Semester 2). Student leaders also attended debriefing meetings with the CÉIM coordinators on a weekly basis.

\section{Student empowerment as an objective of a PAL scheme}

Empowerment is an important, although often under-considered, concept for educators and educational programmers. As Houser and Frymier (2009, p.36) describe 'to be an empowered learner means to be motivated to perform tasks, and more specifically an empowered person finds the tasks meaningful, feels competent to perform them, and feels his/her efforts have an impact on the scheme of things'. Students who meet such a description are more likely to seek help when needed, understand the processes of learning, navigate the third level system to find support, and are less likely to drop-out due to frustrations or fears of failure. However, helping students to become empowered requires the development of certain skills and competencies, including self-directed learning, educational self-efficacy and confidence in negotiating the educational system.

These elements have particular value as outcomes of PAL schemes. Self-directed learning refers to learners taking the initiative in planning, implementing, and evaluating their own 
learning needs and outcomes, individually or within groups (Knowles, 1975). Ultimately, it is about taking responsibility for their own learning rather than simply responding to instruction (Boud, 1981). A meta-analysis of research on self-directed learning found that higher levels of self-directed learning was associated with academic performance, future aspiration, creativity, curiosity, and life satisfaction for students (Edmondson et al., 2012, p.45). Additionally, self-efficacy, referring to an individual's belief in their capacity to organise and execute courses of action in order to reach certain goals or specific performance attainments (Bandura, 1977; 1986; 1997), has been positively associated with academic motivation (Zimmerman, 2000, p.86). Finally, confidence in negotiating the system, while related to self-efficacy, also includes having practical knowledge of educational processes and procedures (Haggis, 2006). For some students, lack of such knowledge increases anxiety around asking questions, accessing services and facilities, and managing examinations and projects. As student bodies diversify, knowledge of academic processes becomes a more significant issue within third level organisations (Haggis, 2006).

A basic assumption of PAL and related schemes is that peer or supplemental learning are not just particular methods, but rather represent an outlook on learning where inner motivation and curiosity are the driving forces and where the main emphasis is on selfgoverning and collective learning (Olstedt 2005, cited Malm et al., 2011a, p.282). PAL schemes are thus implicitly, if not explicitly, concerned with learner empowerment. While a considerable number of studies have evaluated PAL-type schemes by examining academic performance among attendees, non-attendees or by intensity of attendance (e.g. Malm et al., 2011b; Malm et al., 2010; Ogden et al., 2003), fewer studies have focused on changes to learner empowerment as a result of participation. Also underexamined is the impact of student leadership in PAL schemes, with some exceptions such as Malm et al. (2012). To address these gaps, this study considers the impact of participation in the NUI Galway PAL initiative on academic performance among first year students, and assesses student satisfaction with the programme and the contribution of participation on learner empowerment among both first year participants and second year leaders. 


\section{Methodology}

\section{Design}

This article draws from the results of the pilot year (2013/14) of a multi-year evaluative research study on the CÉIM initiative at NUI Galway. The study uses a mixed-methods approach with quantitative and qualitative aspects. Result outcomes for end-of-year final marks and module results were examined to assess the extent to which participation impacts academic performance. Student surveys were adapted from Malm et al. (2010), with the addition of open-ended questions, designed to capture student satisfaction with CÉIM and the extent to which leaders and first year students are empowered as learners through participation. Students and leaders were surveyed online at the end of Semester 1 (September - December) and Semester 2 (January - April). Reflections from two students who participated as first year students in the pilot year and as student leaders in the second year were also solicited.

\section{Participants and procedures}

The first year programme in engineering has 266 students. The analysis of academic performance reflected the outcomes of this cohort. In total 197 first year students in semester 1 ( $73 \%$ of all first year students) and 70 (30\% of all first year students) in semester 2 completed the survey. Among the 23 leaders involved in CÉIM in 2013/14, 16 completed the survey in Semester 1 and 11 completed the survey in Semester 2.

Completion of surveys was voluntary and students and leaders were fully informed through the written introduction of the purpose of the surveys. Participants consented to participate through their completion and submission of the survey. Not all students responded to all questions, resulting in different sample sizes for questions.

The reflections were provided by two students who participated in first year and subsequently as second year leaders (Eniola and Steven). They were contacted by the Students' Union in April 2015 and asked to reflect on their experience with CÉIM over their two years of participation. Reflections were provided to the Students' Union before being made available for this study. Steven and Eniola consented to the use of their reflections in this paper. 
Quantitative analysis of examination results and survey responses took the form of descriptives, analysis of variance, and correlations using SPSS v. 21. Significance was set at a confidence level of $95 \%($ sig. $=0.05)$. Reflections were analysed through thematic content analysis.

\section{Measures}

To assess the impact of CÉIM participation on academic performance, the results outcome data of both end-of-year final results and individual module results were compared to attendance data. In order to assess the impact of participation on student empowerment, a selection of questions from the student survey (Table 1) and the leader survey (Table 2) were examined as indicators of self-directed learning and self-efficacy. Comments indicating the development of confidence in navigating the system emerged spontaneously through the question, 'What is the benefit of CÉIM sessions?' among first year students. The reflective narratives from the two student participants who participated as first year students in the pilot year and subsequently as student leaders in year two were assessed via thematic content analysis under the themes of self-directed learning, self-efficacy, and confidence in navigating the system.

Table 1. Student survey questions used for analysis of student empowerment.

\begin{tabular}{|c|c|c|}
\hline Question & Self-directed learning & Self-efficacy \\
\hline \multirow{4}{*}{$\begin{array}{l}\text { Closed survey } \\
\text { questions: To } \\
\text { what extent do } \\
\text { you agree with } \\
\text { the following } \\
\text { statement: }\end{array}$} & $\begin{array}{l}\text { I have improved my own way of } \\
\text { studying }\end{array}$ & $\begin{array}{l}\text { I gained a considerably deeper } \\
\text { understanding of course content }\end{array}$ \\
\hline & $\begin{array}{l}\text { I have developed my ability to } \\
\text { work with others }\end{array}$ & $\begin{array}{l}\text { I found it easy to ask questions in } \\
\text { CÉIM Sessions }\end{array}$ \\
\hline & $\begin{array}{l}\text { I have improved my skills in } \\
\text { problem-solving }\end{array}$ & I have improved my self-confidence \\
\hline & $\begin{array}{l}\text { I have trained my ability to } \\
\text { discuss tasks in the subject }\end{array}$ & $\begin{array}{l}\text { I have developed my ability to work } \\
\text { with others }\end{array}$ \\
\hline Open questions: & $\begin{array}{l}\text { What are the benefits of } \\
\text { attending CÉIM? }\end{array}$ & $\begin{array}{l}\text { Name and explain three skills that } \\
\text { you developed through participation } \\
\text { in CÉIM }\end{array}$ \\
\hline
\end{tabular}


Table 2. Leader survey questions used for analysis of student empowerment.

\begin{tabular}{|l|l|l|}
\hline Question & $\begin{array}{l}\text { Self-directed } \\
\text { learning }\end{array}$ & Self-efficacy \\
\hline $\begin{array}{l}\text { Closed survey questions: } \\
\begin{array}{l}\text { To what extent do you } \\
\text { agree with the following } \\
\text { statement: }\end{array}\end{array}$ & $\begin{array}{l}\text { I improved the planning of } \\
\text { my own work }\end{array}$ & $\begin{array}{l}\text { I have developed my ability to make a group } \\
\text { of individuals enthusiastic about performing a } \\
\text { task }\end{array}$ \\
\cline { 2 - 3 } & $\begin{array}{l}\text { I improved my own way of } \\
\text { studying }\end{array}$ & $\begin{array}{l}\text { I gained a considerably deeper } \\
\text { understanding of the course content }\end{array}$ \\
\cline { 2 - 3 } & $\begin{array}{l}\text { Name and explain three } \\
\text { skills that you have } \\
\text { improved as a result of } \\
\text { participation in CÉIM }\end{array}$ & $\begin{array}{l}\text { Name and explain three skills that you have } \\
\text { improved as a result of participation in CÉlM } \\
\text { help each other }\end{array}$ \\
\hline Open questions: & \begin{tabular}{l} 
Imy ability to get students to \\
\hline
\end{tabular} & \\
\hline
\end{tabular}

\section{Findings and discussion}

In the following section, findings from the pilot year of CÉIM are presented in three parts. First, the analysis of the impact of CÉIM attendance on academic performance is presented. Second, the analysis of student satisfaction of CÉIM from the first year student survey is presented and the development of student empowerment, as expressed through the perceived development of self-directed learning and self-efficacy, and confidence in navigating the system, is considered. In the third part, findings from the leaders' survey are presented and responses are evaluated from the perspective of student empowerment through the development of self-directed learning and self-efficacy. Narrative contributions drawn from the reflections of the two students who participated as both first year student participants and second year leaders provide additional material to contextualise the survey, and examination results and are used to introduce the various sections. 


\section{Impact on academic performance among first year students}

In Semester 2 I was having some trouble with the subject of Physics and I expressed my concerns with [sic] the CÉIM leaders...I subsequently received an ' $A$ ' in Physics which I don't think I would have achieved without the help of CÉIM. (Steven)

Overall first year examination results were compared to CÉIM attendance to determine if a positive association between examination results and attendance existed. All first year engineering students took the same set of compulsory modules regardless of their discipline. To exclude the possibility that a positive relationship between attendance and results could be the outcome of a particular cohort of students attending CÉIM sessions more often, rather than CÉIM itself influencing the results, analysis using Pearson's Correlation included the factors of examination results, attendance at CÉIM and Central Applications Office (CAO) entry points. (CAO entry points refer to the points achieved in final examinations in secondary school (second-level) in the Irish educational system. The CAO entry points are used to set minimum requirements by courses and for students to gain entry into third level education).

A positive association of attendance at CÉIM sessions with overall results was found $(r=0.178, p<0.05)$, while, as expected, CAO entry points were also positively correlated with result outcomes $(r=0.676, p<0.000)$. Attendance at CÉIM and CAO entry points did not have a significant relationship. Thus while CAO entry points was a stronger predictor of result outcomes, with those with higher entry points more likely to achieve higher results, attendance at CÉIM nevertheless was associated with higher result outcomes, regardless of entry points. Indeed, as no significant association was found between CAO entry points and attendance at CÉIM, entry points to university did not appear to influence whether a student would attend CÉIM sessions or the benefit of CÉIM attendance on academic performance. Although the relationship between attendance and performance was not very strong, it is likely that the numbers attending CÉIM sessions often in the first year of the pilot (35\% attended sessions once per month or more often) impacted the strength of the association.

Further evidence of the value of CÉIM to student outcomes was found when splitting the group between regular attendees at CÉIM sessions (three or more sessions in Semester 
1) and those who attended irregularly or not at all, and comparing the mean (average) result outcomes of these two groups using the ANOVA test of variance. It was found that, on average, regular attendees achieved $7 \%$ higher grades than irregular attendees, with regular attendees achieving an average result at the end of first year of $61 \%$ (a second class honours level one), in comparison to 54\% (a second class honours level two) for non/irregular attendees (see Table 3). Furthermore, when CÉIM attendance was assessed against specific module outcomes (mean results), statistically significant relationships were again found, with improved results among regular CÉIM attendees in seven out of nine core modules taken in first year engineering. Results are presented in Table 3.

The findings in Table 3 indicate an association between result outcomes and regular attendance at CÉIM. In order to validate and provide context to these results, the student surveys were examined to gain insight into students' own views of CÉIM and the benefits which they perceived having derived from the programme. We present these findings in the following sections.

\section{First year students: benefits of participation and influence of CÉlM on student empowerment}

\section{Satisfaction and self-perceived benefits of participation}

Having experienced the value of group study sessions, I now arrange to meet with my peers to revise for exams, to supplement studying by myself. I also feel my confidence to work in a group and self-esteem has improved dramatically. (Steven)

In the relaxed environment of the small classroom...I found it much easier to talk to my CÉIM student leaders about my concerns. (Eniola)

Reflecting Steven and Eniola's experience, students generally reported positively on their participation in CÉIM in the surveys in both Semesters 1 and 2. (In the analysis of survey results, students who reported never having attended a CÉIM session were excluded from analysis of questions relating directly to the programme). A particularly high positive rate of satisfaction was found among those who attended sessions regularly, with over $90 \%$ expressing satisfaction with the sessions and their leaders and $100 \%$ stating that they 
Table 3. ANOVA (Analysis of Variance) for result outcomes by subject and attendance at CÉlM sessions.

\begin{tabular}{|c|c|c|c|c|c|c|}
\hline \multicolumn{2}{|l|}{ Course } & $\mathbf{n}$ & Mean & df & $\mathbf{F}$ & Sig. \\
\hline \multirow{3}{*}{$\begin{array}{l}\text { Mathematical } \\
\text { Methods }\end{array}$} & Regular Attendance & 46 & 49 & 1 & 5.323 & $.022^{*}$ \\
\hline & no/irregular attendance & 210 & 42 & 254 & & \\
\hline & Total & 256 & 43 & 255 & & \\
\hline \multirow[t]{3}{*}{ Chemistry } & Regular Attendance & 46 & 49 & 1 & 1.969 & .162 \\
\hline & no/irregular attendance & 210 & 45 & 254 & & \\
\hline & Total & 256 & 46. & 255 & & \\
\hline \multirow[t]{3}{*}{ Computing } & Regular Attendance & 46 & 62 & 1 & 7.241 & $.008^{*}$ \\
\hline & no/irregular attendance & 209 & 54 & 253 & & \\
\hline & Total & 255 & 55. & 254 & & \\
\hline \multirow{3}{*}{$\begin{array}{l}\text { Fundamentals Of } \\
\text { Engineering }\end{array}$} & Regular Attendance & 46 & 58. & 1 & 6.720 & $.010^{*}$ \\
\hline & no/irregular attendance & 209 & 52 & 253 & & \\
\hline & Total & 255 & 53 & 254 & & \\
\hline \multirow[t]{3}{*}{ Engineering Design } & Regular Attendance & 46 & 63 & 1 & 4.413 & $.037^{*}$ \\
\hline & no/irregular attendance & 210 & 59 & 254 & & \\
\hline & Total & 256 & 60 & 255 & & \\
\hline \multirow{3}{*}{$\begin{array}{l}\text { Engineering } \\
\text { Graphics }\end{array}$} & Regular Attendance & 46 & 80 & 1 & 16.748 & $.000^{\star *}$ \\
\hline & no/irregular attendance & 219 & 71 & 263 & & \\
\hline & Total & 265 & 72 & 264 & & \\
\hline \multirow{3}{*}{$\begin{array}{l}\text { Engineering } \\
\text { Calculus }\end{array}$} & Regular Attendance & 46 & 56 & 1 & 5.957 & $.015^{\star}$ \\
\hline & no/irregular attendance & 210 & 49 & 254 & & \\
\hline & Total & 256 & 50 & 255 & & \\
\hline \multirow{3}{*}{$\begin{array}{l}\text { Engineering } \\
\text { Mechanics }\end{array}$} & Regular Attendance & 46 & 66 & 1 & 3.781 & .053 \\
\hline & no/irregular attendance & 210 & 60 & 254 & & \\
\hline & Total & 256 & 61 & 255 & & \\
\hline \multirow[t]{3}{*}{ Physics } & Regular Attendance & 46 & 57 & 1 & 4.241 & $.040^{*}$ \\
\hline & no/irregular attendance & 209 & 51 & 253 & & \\
\hline & Total & 255 & 52 & 254 & & \\
\hline \multirow{3}{*}{$\begin{array}{l}\text { Overall Average } \\
\text { result }\end{array}$} & Regular Attendance & 46 & 61 & 1 & 8.018 & $.005^{\star}$ \\
\hline & no/irregular attendance & 220 & 54 & 264 & & \\
\hline & Total & 266 & 56 & 265 & & \\
\hline
\end{tabular}


found it easy to ask questions during sessions in the end-of-year survey. In contrast, those who attended less often had lower satisfaction with sessions (39\%), although the majority of these were still positive about the ability to ask questions, the role of leaders, and agreed that they would encourage others to participate in the sessions (Table 4).

Table 4. Satisfaction: first year students (Semester 2 survey).

\begin{tabular}{|c|c|c|c|}
\hline \multirow[b]{2}{*}{ Statement: } & \multicolumn{3}{|c|}{ Agree with statement below* } \\
\hline & $\begin{array}{c}\text { All } \\
(\mathrm{N}=66)\end{array}$ & $\begin{array}{l}\text { Attended } \\
\text { more than } \\
\text { once/mont } \\
\mathrm{h}(\mathrm{n}=24)\end{array}$ & $\begin{array}{l}\text { Attended } \\
\text { monthly or } \\
\text { less } \\
(\mathrm{N}=33)\end{array}$ \\
\hline $\begin{array}{l}\text { I found it easy to ask questions in CÉIM } \\
\text { sessions }\end{array}$ & $74 \%$ & $100 \%$ & $70 \%$ \\
\hline $\begin{array}{l}\text { Overall, I am satisfied with the CÉIM } \\
\text { sessions }\end{array}$ & $56 \%$ & $92 \%$ & $39 \%$ \\
\hline $\begin{array}{l}\text { I found the leaders helpful in facilitating the } \\
\text { sessions }\end{array}$ & $70 \%$ & $96 \%$ & $64 \%$ \\
\hline $\begin{array}{l}\text { I would encourage others to participate in } \\
\text { CÉIM sessions }\end{array}$ & $65 \%$ & $88 \%$ & $59 \%$ \\
\hline
\end{tabular}

* Data is not included here about neutral responses to the statements or disagreement with the statements.

Responses relating to self-perceived skills development also noted distinctions between those who attended regularly and those that did not, with regular attendees noting high rates of agreement with the development of a range of skills and competencies as shown in Table 5. 
Table 5. Skills development through CÉIM (Semester 2 survey) - first year participants.

\begin{tabular}{lccc}
\hline $\begin{array}{l}\text { Statement: } \\
\text { All }\end{array}$ & $\begin{array}{c}\text { Agree with statement below } \\
\text { Attended more than } \\
\text { once/ month (n=24) }\end{array}$ & $\begin{array}{c}\text { Attended monthly } \\
\text { or less (N=33) }\end{array}$ \\
\hline $\begin{array}{l}\text { I have developed my ability to } \\
\text { communicate with others }\end{array}$ & $47 \%$ & $75 \%$ & $36 \%$ \\
$\begin{array}{l}\text { I feel more secure in being part } \\
\text { of a group }\end{array}$ & $55 \%$ & $79 \%$ & $48 \%$ \\
$\begin{array}{l}\text { I gained a considerably deeper } \\
\text { understanding of course content }\end{array}$ & $51 \%$ & $79 \%$ & $45 \%$ \\
$\begin{array}{l}\text { I have developed my ability to } \\
\text { work with others }\end{array}$ & $44 \%$ & $63 \%$ & $39 \%$ \\
$\begin{array}{l}\text { I have improved my skills in } \\
\text { problem-solving }\end{array}$ & $36 \%$ & $46 \%$ & $36 \%$ \\
$\begin{array}{l}\text { I have trained my ability to } \\
\text { discuss tasks in the subject }\end{array}$ & $55 \%$ & $79 \%$ & $48 \%$ \\
I have improved my self- \\
$\begin{array}{l}\text { confidence } \\
\text { I have improved my ability to } \\
\text { talk in front of others } \\
\text { I have improved my own way of } \\
\text { studying }\end{array}$ & $45 \%$ & $75 \%$ & $39 \%$ \\
\hline
\end{tabular}

* Data is not included here about neutral responses to the statements or disagreement with the statements.

Overall, the survey suggests that those who attended CÉIM regularly perceived benefits in relation to a range of skills and competencies. However, it does not clarify whether students who attended less often were less positive about the benefits of CÉIM because of their irregular attendance, or whether they attended less often because they perceived few benefits. Given the view that student empowerment acts as a bridge to learner development and has significant benefits not only within academia but across the lives of students, it was deemed important to review the narrative responses in conjunction with 
the closed questions of the survey to better understand the ways in which CÉIM participation may contribute to student empowerment.

\section{Influence of CÉIM on student empowerment: development of self-directed learning, self-efficacy and confidence in navigating the system}

To understand the influence of CÉIM on student empowerment, responses to questions on the first year student survey relating to the areas of self-directed learning, self-efficacy, and confidence in navigating the system, as well as relevant open-ended questions, were assessed. The findings of the analysis are presented below under the relevant theme.

\section{Self-directed learning}

While first year students rated the development of skills in problem-solving and the development of 'my own way of studying' resulting from attendance at CÉIM least positively of the skills listed overall, differences were nevertheless noted: those with regular CÉIM attendance reported more positively on these skills compared to irregular attendees. (N.B. The terminology of 'my own way of studying' may have been unclear to some students and consequently may have contributed to low positive responses). As shown in Table 5 above, just over a third of all students agreed that these skills had improved by the end of Semester 2, while approximately half of regular CÉIM attendees agreed that these skills had improved.

The majority of students also indicated that they had (i) improved their ability to work with others, and (ii) trained their ability to ask questions and discuss tasks in a subject, with regular CÉIM attendees responding very positively to these statements (Table 5). Among the open-ended questions, a large number of students mentioned the benefits of working through problems with peers and particular techniques they found helpful. It is possible that students may under-rate how skills such as group work contribute to problem-solving. Of note, leaders reflected positively on the first year students' developing capacity for selfdirected learning, noting, 'you see a real improvement in the first years' understanding of course material, [it is] very rewarding to see them teach and help each other with little involvement of leaders'. Results suggest that attendance at CÉIM sessions positively impacted self-directed learning, with those who attend regularly indicating greater benefits in this area. 


\section{Self-efficacy}

Across all questions relating to skills, those who attended CÉIM sessions regularly expressed a greater level of agreement, suggesting a stronger belief in their developing learning abilities, thus indicating self-efficacy, compared to irregular attendees. First year students were also asked to briefly name and explain three skills they improved upon by participating in CÉIM. The most common skill that students felt they had gained was in relation to communication skills. This was mentioned specifically and spontaneously by 16 students or $44 \%$ of respondents ( $n=36$ ). Team work was identified by 14 respondents; problem-solving skills were mentioned by nine, confidence by nine, and public speaking by nine.

The results indicate that students who participated in CÉIM regularly felt that they had developed a range of skills throughout the year through participation. CÉIM thus appears to have contributed to participating students' self-efficacy.

\section{Confidence in navigating the system}

First year students are often intimidated by the apparent complexities of the university system. Empowered students have confidence in their ability to face challenges and feel secure in negotiating experiences such as examinations, projects, class participation, and other elements of their course. When first year students who attended CÉIM sessions were asked about the benefits of CÉIM, a common response was to state that it helped them feel 'more settled' and that they had benefitted from the practical guidance provided by the second year leaders. For instance, two students explained that:

I had the opportunity to talk to someone who had been through first year themselves and get their advice on exams, assignments and certain modules. (First year student, Semester 1)

[l] felt more prepared for exams and had a better idea what to expect [due to CÉIM participation]. (First year student, Semester 2)

These spontaneous responses highlight the important role of student leaders in helping first year students navigate the university system and better understand academic processes. Attendance at CÉIM sessions, particularly the interaction between leaders and 
first year students, thus appears to have assisted in the development of confidence in navigating the system for first year student participants.

\title{
Second year leaders: satisfaction with CÉlM and influence of CÉlM on student empowerment
}

\author{
I found the benefits of CÉIM didn't stop for me just because I was a student \\ but rather they continued and advanced [as a leader]. Seeing collaborative \\ learning in action...highlighted the importance of group study to me and I \\ even set up my own group study session with some friends! (Eniola)
}

Being a CÉIM leader really helped to develop my organisational and time management skills which I was then able to apply on a personal level, managing my own workload. (Steven)

Both Eniola and Steven indicated that participation in second year as a student leader reenforced the skills they had gained as first year CÉIM participants and enabled this learning to be applied in practice; for Eniola through the development of her own group study session and for Steven through workload management. In the following sections leaders' perceptions of CÉIM are examined and the influence of CÉIM on student empowerment for second year leaders is considered.

\section{Satisfaction and self-perceived benefits of CÉIM: leaders}

Like Steven and Eniola, leaders who participated in the surveys during the pilot year $(\mathrm{n}=16$ in Semester 1, $n=11$ in Semester 2) noted that leadership improved their study skills and their confidence in their ability to lead others, although unlike Steven and Eniola, they did not have the opportunity to benefit from being both first year student participants and student leaders as this was the pilot year. Nevertheless, analysis of the Semester 2 leader survey questions relating to confidence and leadership demonstrated highly positive responses, as shown in Table 4. 
In Semester 2, leaders were also asked to identify three skills which they had improved through participation in CÉIM $(n=11)$. Nine leaders stated that they had improved their leadership skills, while eight respondents noted improvements to their communication skills. A further eight noted an improvement in organisation or time-management. One leader details the impact of CÉIM on their own educational career as having changed 'my approach to studying in that I can see there's a lot more to be gained from studying in a group. More ideas mean a better overall understanding'. These findings provide support to other studies that similarly found self-identified improvements in leadership, communication and confidence (Malm et al., 2012; Lockie and Van Lanen, 2008).

\section{Influence of CÉIM on student empowerment of leaders: development of self-directed learning and self-efficacy}

In relation to self-directed learning, second year leaders were more positive about the improvement of the planning of their own work and developing their own way of studying by the end of the year (see Table 6) in comparison to first year students (see Table 5). Given Eniola and Steven's positive experience, and their view that skills were developed through both first and second year involvement in CÉIM, it is likely that self-directed learning is a more complex skill that requires more intensive involvement in such schemes, and may be realised more frequently in the second year of involvement.

The experience of leading CÉIM sessions appears to improve self-efficacy among leaders, however, confidence in navigating the system did not emerge from leader responses, as it did with first year students. This may be because second year students are likely to have already acquired confidence in this area during their first year, or it may be that those who are confident in navigating the system are those who are most likely to take up the role of leader. Overall, evidence suggests that student empowerment is improved through participation as a student leader. As indicated by Eniola and Steven's experience, participation as both a first year student and a second year leader is likely to intensify the beneficial effects of CÉIM. 
Table 6. Perception of skills development - student leaders, Semester 2.

Statement:

Agree

$(n=11)$

\begin{tabular}{lc}
\hline $\begin{array}{l}\text { I have developed my ability to communicate with } \\
\text { others }\end{array}$ & $100 \%$ \\
I feel more secure in being a leader of a group & $100 \%$ \\
I have improved in organising the work for a group & $91 \%$ \\
I have developed my ability to listen to other people's & $91 \%$ \\
thoughts and reasoning & \\
I feel more secure in leading a discussion & $100 \%$ \\
I have developed my ability to make a group of & $91 \%$ \\
individuals enthusiastic about performing a task & \\
I gained a considerably deeper understanding of the & $73 \%$ \\
course content & \\
I have developed my ability to get students to help & $91 \%$ \\
each other & $91 \%$ \\
I have improved my self-confidence & $100 \%$ \\
I improved my ability to talk in front of others & $73 \%$ \\
I improved my ability to meet and inspire different & \\
individuals & $64 \%$ \\
I improved the planning of my own work & $45 \%$ \\
I improved my own way of studying & $100 \%$ \\
\hline I would encourage others to become a CÉlM leader & \\
\hline
\end{tabular}

\section{Discussion and conclusions}

This study suggests that PAL schemes, such as the CÉIM shared learning initiative at NUI Galway, can positively contribute towards improved academic performance and student empowerment. First year students who attended CÉIM sessions regularly demonstrated, on average, an overall result outcome $7 \%$ higher than those who did not attend regularly. They also demonstrated greater levels of educational self-efficacy and confidence in navigating the educational system. The perceived development of self-directed learning 
skills was not as high as the aforementioned skills; nevertheless, those who participated regularly in CÉIM were more than twice as likely to state they had improved their own way of studying. While it cannot be ruled out that students with greater empowerment are more likely to participate in CÉIM, rather than CÉIM leading to improved empowerment, the narrative responses by students and the student reflections substantiate the view that CÉIM participation contributes towards student empowerment. These findings echo results from other studies that have evaluated similar programmes in relation to academic performance (e.g. Malm et al., 2011b) and development of skills associated with learner empowerment (e.g. Ginty and Harding, 2014; Zraa et al., 2013; Malm et al., 2010).

Participating in CÉIM as a student leader also demonstrated benefits. CÉIM second year leaders noted increased skills in leadership, communication and confidence. Although less than half felt they had improved their 'own way of studying', almost two thirds stated that they had improved the planning of their work. The reflective contributions provide evidence that benefits accrue across multiple years of involvement and further suggest that selfdirected learning develops over time, and potentially following the development of selfefficacy.

The evidence thus suggests that student empowerment is an ongoing process that is most likely to be achieved through participation across multiple years of education, as both student participants and student leaders. For schools and institutions currently running PAL schemes, and those considering their roll-out, it may therefore be important to examine the possibilities of extending student involvement beyond second year into third and potentially fourth year, for instance in coordination roles, to ensure that students, and programmes, reap the full benefits of such initiatives. Further research on the benefits of PAL schemes across multiple years is needed to determine the benefits versus costs of extending programmes.

It is clear that students placed value on learning about academic processes from student leaders. This finding corroborates the view that 'integrated and coordinated peer mentoring and peer learning activities may increase the capacity of universities to meet the specific needs of their student cohorts' (Townsend et al., 2011, p.74). Placing more emphasis during leader training on methods of sharing knowledge about academic processes/navigating the system within sessions may have benefits for all involved. 


\section{Lessons and recommendations for improvements}

While significant benefits have been found in the pilot year of CÉIM, some changes have been identified to maximise these benefits in subsequent years. For example, greater emphasis was placed on marketing the benefits of attendance in year two of the programme, and emphasising that CÉIM is not a remedial support. From 2015/16 onwards, leaders will be provided with pastoral training in health and wellbeing in addition to their facilitator training, and Student Leader Coordinators (third year students who participated in CÉIM in their first year and acted as leaders in their second year) will coach the leaders.

\section{Conclusions}

The findings of this study support the view that PAL programmes contribute towards improved academic performance among those who attend and further suggest that such programmes may contribute more broadly to learner empowerment within third level institutions. Regular attendance at CÉIM was associated with better examination result outcomes, a growth in confidence in navigating the educational system, self-efficacy, and, to a somewhat lesser extent, the development of self-directed learning among first year students. Participation as a student leader was associated with improved leadership skills and further development of independent learning skills. These findings suggest that CÉIM and other PAL programmes have much to offer university programmes and are likely to help address issues of satisfaction and retention among participating students and student leaders.

\section{References}

Bandura, A. (1977) 'Self-efficacy: toward a unifying theory of behavioral change', Psychological Review, 84(2), pp. 191-215.

Bandura, A. (1986). Social foundations of thought and action: a social cognitive theory. Englewood Cliffs, NJ: Prentice-Hall.

Bandura, A. (1997) Self-efficacy: the exercise of control. New York, NY: W.H. Freeman. 
Boud, F. (1981) Developing student autonomy in learning. London: Kogan.

Edmondson, D.R., Boyer, S.L., and Artis, A.B. (2012) 'Self-directed learning: a metaanalytic review of adult learning constructs', International Journal of Education Research, 7(1), pp. 40-48.

Ginty, C. and Harding, N.M. (2014) 'The first year experience of a peer assisted learning program in two institutes of technology in Ireland', Journal of Peer Learning, 7(2014), pp. 36-56. Available at: http://ro.uow.edu.au/ajpl/vol7/iss1/5 (Accessed: 15 November 2015).

Haggis, T. (2006) 'Pedagogies for diversity: retaining critical challenge amidst fears of 'dumbing down', Studies in Higher Education, 31(5), pp. 521-535.

Houser, M.L. and Frymier, A.B. (2009) 'The role of student characteristics and teacher behaviors in students' learner empowerment', Communication Education, 58(1), pp. 35-53.

Knowles, M.S. (1975) Self-directed learning: a guide for learners and teachers. Englewood Cliffs, NJ: Prentice Hall.

Lockie, N.M. and Van Lanen, R.J. (2008) 'Impact of the Supplemental Instruction experience on science SI leaders', Journal of Developmental Education, 31(3), pp. $2-14$.

Malm, J., Bryngfors, L. and Mörner, L. (2010) 'Supplemental Instruction (SI) at the Faculty of Engineering (LTH), Lund University, Sweden: an evaluation of the SI program at five LTH engineering programs, Autumn 2008', Australian Journal of Peer Learning, 3(1), pp. 38-50.

Malm, J., Bryngfors, L. and Mörner, L. (2011a) 'Supplemental Instruction: whom does it serve?', International Journal of Teaching and Learning in Higher Education, 23(3), pp. 282-291. 
Malm, J., Bryngfors, L. and Mörner, L. (2011b) 'Improving student success in difficult engineering education courses through Supplemental Instruction (SI) - what is the impact of the degree of SI attendance?', Journal of Peer Learning, 4(1), pp. 16-23.

Malm, J., Bryngfors, L. and Mörner, L. (2012) 'Benefits of guiding Supplemental Instruction sessions for SI leaders: a case study for engineering education at a Swedish University', Journal of Peer Learning, 5(1), pp. 32-41.

Ogden, P., Thompson, D., Russell, A. and Simons, C. (2003) 'Supplemental Instruction: short- and long-term impact', Journal of Developmental Education, 26(3), pp. 2-8.

Thomas, L. (2012) Building student engagement and belonging in higher education at a time of change: final report from the What Works? Student Retention \& Success programme. Available at:

https://www.heacademy.ac.uk/sites/default/files/what works final report.pdf (Accessed: 15 November 2015).

Townsend, R.A., Delves, M., Kidd, T. and Figg, B. (2011) 'Undergraduate student peer mentoring in a multi-faculty, multi-campus university context', Journal of Peer Learning, 4(1), pp. 37-49 [Online]. Available at: http://ro.uow.edu.au/ajpl/vol4/iss1/6 (Accessed: 15 November 2015).

van der Meer, J. and Scott, C. (2008) 'Shifting the balance in first-year learning support: from staff instruction to peer-learning primacy', Journal of Peer Learning, 1(1), pp. 70-79. Available at: http://ro.uow.edu.au/ajpl/vol1/iss1/9 (Accessed: 15 November 2015).

Zimmerman, B.J. (2000) 'Self-efficacy: an essential motive to learn', Contemporary Educational Psychology, 25(1), pp. 82-91.

Zraa, W., Kavanagh, W. and Johnson Morgan, M. (2013) 'The impact of cooperative learning and empowerment on the performance of first-year accounting students', Journal of Modern Accounting and Auditing, 9(3), March, pp. 348-355. 


\section{Author details}

Stacey Scriver, PhD, is a post-doctoral researcher in the School of Political Science and Sociology, NUI Galway and an independent social and educational researcher. Key research interests include impact evaluation of community based interventions on health, gender and education in a variety of contexts. She is the lead researcher in the evaluation of CÉIM at NUI Galway.

Amber Walsh Olesen coordinates the CÉIM initiative and is based at NUI Galway Students' Union. She has a background in programme management and marketing, with specific experience in supporting start-ups and process design. Her current key interests include student-led innovation and supporting successful transitions in higher education.

Eoghan Clifford, $\mathrm{PhD}$, is a lecturer at the College of Engineering \& Informatics at NUI Galway. $\mathrm{He}$ is the academic director of the first year engineering programme at NUI Galway and, with Amber Walsh Olesen, coordinates CÉIM. He teaches both undergraduate and postgraduate modules. His main areas of research include environmental and transport engineering. 